\title{
HUBUNGAN ANTARA STATUS SOSIAL EKONOMI ORANG TUA DENGAN USIA PERKEMBANGAN ANAK USIA 3-5 TAHUN DI TK SENTOSA BHAKTI BATURAJA
}

\author{
Yudi Budianto, S.Kep., Ns., M.Kes \\ Akademi Keperawatan - AKPER AL-MA'ARIF BATURAJA \\ E-mail: yudikian@yahoo.com
}

\begin{abstract}
ABSTRAK
Pendahuluan: Status sosial ekonomi adalah suatu pengelompokan orang-orang berdasarkan kesamaan karakteristik pekerjaan, pendidikan dan ekonomi. Status sosial ekonomi menunjukkan ketidaksetaraan tertentu. perkembangan anak adalah segala perubahan yang terjadi pada diri anak dilihat dari berbagai aspek antara lain aspek fisik (motorik), emosi, kognitif dan psikososial bagaimana anak berinteraksi dengan lingkungan. Tujuan penelitian ini adalah untuk mengetahui hubungan antara status social ekonomi orang tua dengan usia perkembangan anak usia 3-5 tahun. Penelitian ini dilakukan di TK Sentosa Bhakti Baturaja Tahun 2019 sampel dalam penelitian ini sebanyak 54 siswa/i. Metode Penelitian: merupakan penelitian deskriptif. Pengumpulan data dalam penelitian ini dilakukan secara door to door dalam satu kali waktu pengisisan, kuesioner yang telah diisi selanjutnya di lakukan pengolahan data meliputi editing, coding, entry, cleaning. Hasil Penelitian: didapatkan bahwa nilai $p$ value $0,013(<0,05)$ artinya ada hubungan yang bermakna antara status sosial ekonomi orang tua terhadap usia perkembangan anak. Penelitian ini menggunakan uji statistic (hipotesis) yang dilakukan dengan pengujian Chisquare.
\end{abstract}

Kata Kunci : Status Sosial Ekonomi, Usia Perkembangan Anak, Siswa

\begin{abstract}
Introduction: Socioeconomic status is a grouping of people based on similar characteristics of work, education and economy. Socioeconomic status indicates certain inequalities. child development is all the changes that occur in the child seen from various aspects including physical (motor), emotional, cognitive and psychosocial aspects of how children interact with the environment. The purpose of this study was to determine the relationship between the socioeconomic status of parents with the age of development of children aged 3-5 years. This research was conducted in Sentosa Bhakti Baturaja Kindergarten in 2019. The samples in this study were 54 students. Research Methods: is a descriptive study. Data collection in this study was carried out door-to-door in one time filling, the questionnaire that was filled in then carried out data processing including editing, coding, entry, cleaning. Research Results: found that the $p$ value of $0.013(<0.05)$ means that there is a significant relationship between the socioeconomic status of parents to the child's developmental age. This study uses a statistical test (hypothesis) which is done by Chi-square testing.Keyword: Socio-Economic Status, Age of Child Development, Students
\end{abstract}

\section{Keyword: Socio-Economic Status, Age of Child Development, Students}




\section{PENDAHULUAN}

Status sosial ekonomi adalah suatu pengelompokan orang-orang berdasarkan kesamaan karakteristik pekerjaan, pendidikan dan ekonomi (Santrock. 2009).

The United Nations Children's Fund (UNICEF) menyebutkan bahwa malnutrisi pada balita dapat menyebabkan terganggunya pola pertumbuhan dan perkembangan anak dimasa depan. Sebuah studi yang dilakukan di Philippines menunjukkan bahwa dari 2000 anak yang mengalami malnutrisi, 2/3 diantaranya mengalami penurunan Intelligence Quotient (IQ).

Menurut RIKESDAS tahun 2013 pengukuran status ekonomi merupakan salah satu cara yang sering digunakan untuk mengukur tingkat kesejahteraan suatu rumah tangga. Status ekonomi rendah pada keluarga akan berdampak dengan kemiskinan. Dalam penelitian UNICEF tahun 2010 salah satu faktor pencetus gangguan tumbuh kembang anak adalah kemiskinan. Kemiskinan menyebabkan keluarga tidak mampu memenuhi kebutuhan gizi balita karena ketidaksanggupan dalam pemenuhan bahan pangan sehingga balita mengalami gangguan pertumbuhan dan perkembangan (Kemenkes RI, 2013).

Status sosial ekonomi rendah mengakibatkan kebutuhan makanan keluarga akan kurang terpenuhi sehingga anak akan memiliki status gizi kurang (Basrowi, 2010). Akibat gizi buruk pada balita, mereka akan mengalami gangguan pertumbuhan dan perkembangan baik fisik maupun kecerdasan. Saat ini, keterlambatan tumbuh kembang pada anak masih menjadi masalah serius di negara maju maupun negara berkembang di dunia.

Angka kejadian keterlambatan perkembangan anak di Amerika Serikat berkisar 12-16\%, Argentina 22\% (Lejarraga, et al., 2008), dan Hongkong 23\% (Usman, et al., 2014). Fenomena ini juga terjadi di Kanada dan Selandia Baru, dimana terdapat $5-7 \%$ anak yang mengalami gangguan perkembangan sosial (Suyami, et al., 2016). Sementara itu, gangguan perkembangan pada anak di Thailand mencapai 37,1\% (Jeharsae, et al., 2013) dan di India berkisar 19,8\% (Ali, et al., 2011). Keterlambatan perkembangan anak ini terjadi sebagian besar di wilayah Asia dan Afrika (Grantham, et al., 2007).

Balita di Indonesia berjumlah 23,7 juta jiwa atau sekitar $10,4 \%$ dari total penduduk Indonesia (IDAI, 2008). Namun hingga saat ini, angka gangguan perkembangan anak di Indonesia masih cukup tinggi. Profil kesehatan Indonesia tahun 2011 menunjukkan bahwa 13-18\% anak balita mengalami keterlambatan perkembangan (Usman, et al., 2014). Berdasarkan penelitian yang dilakukan di Rumah Sakit Anak dan Bunda Harapan Kita, terdapat 30,9\% anak mengalami keterlambatan perkembangan (Tjandrajani, et al., 2012). Sementara hasil skrining perkembangan anak yang dilakukan Depkes RI pada 30 provinsi didapatkan data gangguan perkembangan pada anak sebesar 45,12\% (Christiari, et al., 2013).

Salah satu yang sangat dibutuhkan pada tahap perkembangan anak yaitu nutrisi yang menjadi salah satu komponen yang penting dalam menunjang keberlangsungan proses pertumbuhan dan perkembangan. Apabila kebutuhan nutrisi seseorang tidak atau kurang terpenuhi maka dapat menghambat pertumbuhan dan perkembangan anak (Hidayat, 2013:12).

Gizi yang dikonsumsi balita akan berpengaruh pada status perkembangan balita. Perbedaan status gizi balita memiliki pengaruh yang berbeda pada setiap perkembangan anak, dimana jika gizi yang dikonsumsi tidak terpenuhi dengan baik maka perkembangan balita akan dapat menghambat perkembangannya yang meliputi kognitif, motorik, bahasa, dan personal-sosial dalam keterampilannya dibandingkan dengan balita yang memiliki status gizi baik (salsabila, 2010). Tingkat ekonomi keluarga mempengaruhi kemampuan orang tua dalam penyediaan sarana prasarana dalam menstimulasi perkembangan anak (Ambarwati, et al., 2015). 


\section{METODE PENELITIAN}

Penelitian ini merupakan penelitian survei analitik, dengan rancangan Cross Sectional artinya penelitian yang pengukuran atau pengamatannya dilakukan secara simultan pada waktu yang bersamaan (Notoadmojo, 2012). Populasi adalah keseluruhan dari semua variabel yang menyangkut masalah yang

\section{PENELITIAN}

1. Hubungan Antara Status Sosial Ekonomi Orang Tua dengan Usia diteliti (Notoadmojo,2005:24). Populasi penelitian ini adalah seluruh siswa TK Sentosa Bhakti Baturaja Sampel adalah bagian dari populasi terjangkau yang dapat digunakan sebagai subjek penelitian melalui sampling sehingga mewakili populasi yang ada (Notoadmojo, 2005:25)

Perkembangan Anak Usia 3-5 Tahun Di TK Sentosa Bhakti Baturaja Tahun 2019

Tabel. 1

Hubungan Kondisi Hubungan Antara Status Sosial Ekonomi Orang Tua dengan Usia Perkembangan Anak Usia 3-5 Tahun Di TK Sentosa Bhakti Baturaja

\begin{tabular}{|c|c|c|c|c|c|c|c|c|c|c|c|}
\hline \multirow{3}{*}{ No } & \multirow{3}{*}{$\begin{array}{l}\text { Status Sosial } \\
\text { Ekonomi }\end{array}$} & \multicolumn{8}{|c|}{ Usia Perkembangan Anak } & \multirow{3}{*}{ Total } & \multirow{3}{*}{$\begin{array}{c}\mathbf{P} \\
\text { Value }\end{array}$} \\
\hline & & \multicolumn{2}{|c|}{ Advance } & \multicolumn{2}{|c|}{ Normal } & \multicolumn{2}{|c|}{ Caution } & \multicolumn{2}{|c|}{ Delay } & & \\
\hline & & $\mathbf{N}$ & $\%$ & $\mathbf{N}$ & $\%$ & $\mathbf{N}$ & $\%$ & $\mathbf{N}$ & $\%$ & & \\
\hline 1 & Sangat Tinggi & 1 & $33.3 \%$ & 2 & $66.7 \%$ & 0 & $0 \%$ & 0 & $0 \%$ & 3 & \\
\hline 2 & Tinggi & 0 & $0 \%$ & 6 & $100 \%$ & 0 & $0 \%$ & 0 & $0 \%$ & 6 & \\
\hline 3 & Sedang & 1 & $2.6 \%$ & 38 & $97.4 \%$ & 0 & $0 \%$ & 0 & $0 \%$ & 39 & 0.013 \\
\hline \multirow[t]{2}{*}{4} & Rendah & 0 & $0 \%$ & 5 & $83.3 \%$ & 1 & $16.7 \%$ & 0 & $0 \%$ & 6 & \\
\hline & & 2 & $3.7 \%$ & 51 & $94.4 \%$ & 1 & $1.9 \%$ & 0 & $0 \%$ & 54 & \\
\hline
\end{tabular}

Dari hasil table. 1 analisa hubungan status sosial ekonomi terhadap usia perkembangan anak didapatkan p-value 0.013 artinya ada hubungan yang bermakna antara status sosial ekonomi orang tua terhadap usia perkembangan anak.

\section{PEMBAHASAN}

Pada penelitian ini dapat disimpulkan bahwa ada hubungan yang bermakna antara status sosial ekonomi orang tua terhadap usia perkembangan anak usia 3-5 tahun di TK Sentosa Bhakti Baturaja Tahun 2019. Menurut RIKESDAS tahun 2013 pengukuran status ekonomi merupakan salah satu cara yang sering digunakan untuk mengukur tingkat kesejahteraan suatu rumah tangga. Status ekonomi rendah pada keluarga akan berdampak dengan kemiskinan. Dalam penelitian UNICEF tahun 2010 salah satu faktor pencetus gangguan tumbuh kembang anak adalah kemiskinan. Kemiskinan menyebabkan keluarga tidak mampu memenuhi kebutuhan gizi balita karena ketidaksanggupan dalam pemenuhan bahan pangan sehingga balita mengalami gangguan pertumbuhan dan perkembangan (Kemenkes RI, 2013).

Berdasarkan data dari Profil Kesehatan RI (2014), upaya pemeliharaan kesehatan anak dapat dilihat dari pelayanan kesehatan anak balita yang dilakukan oleh tenaga kesehatan, meliputi: pelayanan pemantauan pertumbuhan, (b) pemberian vitamin $A$ dua kali dalam setahun, (c) stimulasi deteksi dan intervensi dini tumbuh kembang balita, dan (d) pelayanan anak balita sakit.

Tingkat ekonomi keluarga mempengaruhi kemampuan orang tua dalam penyediaan sarana prasarana dalam menstimulasi perkembangan anak. Penelitian ini yang dilakukan untuk meningkatkan pengetahuan orang tua tentang pentingnya status gizi bagi proses perkembangan anak, sebab masih didapatkan orang tua dengan penghasilan rendah dengan usia perkembangan anak 
caution yaitu gagal atau menolak tugas pada item dimana garis umur berada di antara $75 \%$ sampai $90 \%$ (warna hijau). Dari hasil penelitian ini menunjukkan terdapat hubungan antara status sosial ekonomi orang tua terhadap usia perkembangan anak di TK Sentosa Bhakti Baturaja Tahun 2019, melalui analisis korelasi crosstabs di peroleh hasil p.value 0,013 dimana p.value lebih kecil dari 0,05 sehingga dapat disimpulkan adanya hubungan yang bermakna antara status sosial ekonomi orang tua terhadap usia perkembangan anak.

Status sosial ekonomi orang tua berpengaruh pada proses perkembangan anak. Siswa yang memilik orang tua yang status sosial ekonominya tinggi akan membantu proses perkembangan anak dan anak dapat berkembang sesuai dengan umurnya. Secara teoritis orang tua yang status sosial ekonominya tinggi dapat memenuhi kebutuhan gizi anak dengan seimbang sehingga tidak ada hambatan dalam proses perkembangan anak. Sebaliknya, orang tua yang status sosial ekonominya rendah akan merasa kesulitan dalam pemenuhan kebutuhan gizi anak.

Keadaan status sosial ekonomi orang tua memepunyai peranan terhadap perkembangan anak, adanya perekonomian yang cukup, lingkungan material yang dihadapianak didalam keluarga lebih luas maka dapat memberikan kesempatan untuk mengembangkan kecakapan. Sebaliknya keluarga yang memiliki status sosial ekonomi cenderung rendah kurang dapat mengembangkan kemampuan karena terhambat dalam hal ekonomi keluarga.

Hubungan orang tua hidup dalam suatu sosial ekonomi serba cukup dan kurang mengalami tekanan-tekanan sehingga orang tua dapat mencurahkan perhatian lebih mendalam kepada anaknya apabila tidak dipenuhi dengan perkara kebutuhan hidup

\section{KESIMPULAN}

1. Peneltian ini menunjukkan orang tua yang memiliki status sosial ekonomi tinggi dapat memenuhi kebutuhan gizi anak dan dapat membantu proses perkembangan anak.

2. Penelitian ini menunjukkan orang tua yang memiliki status ekonomi rendah akan mengalami kesulitan dalam pemenuhan kebutuhan gizi anak sehingga dapat menghambat perkembangan anak.

3. Penelitian ini menunjukkan adanya hubungan yang bermakna antara hubungan status sosial ekonomi orang tua terhadap proses perkembangan anak usia 3-5 tahun di TK Sentosa Bhakti Baturaja Tahun 2019.

\section{DAFTAR PUSTAKA}

1. Arikunto, Suharsimi Dr. Prof. 2002.Prosedur Penelitian Suatu Pendekatan Praktek. Edisi Revisi V, Rineka Cipta, Jakarta.

2. Direktorat Jenderal Pengendalian Penyakit dan Penyehatan Lingkungan (P2PL)., 2011. Pedoman Pengendalian Infeksi Saluran pernapasan Akut. Jakarta : Kementerian Kesehatan RI

3. Erlien, 2008. Penyakit saluran Pernapasan, Sunda Kelapa Pustaka, Jakarta.

4. Ikatan Dokter Anak Indonesia (IDAI). (2014). Pedoman Imunisasi di Indonesia (Edisi kelima). Satgas Imunisasi Ikatan Dokter Anak Indonesia.

5. Kemkes RI, 2017.Infeksi saluran Pernafasan akut, http://www.fuadbahsin.wordpress.co $\mathrm{m}$.

6. Notoatmodjo, Kerangka Teori Hubungan Antara Faktor- Faktor Risiko dengan Kejadian ISPA (Sumber: Modifikasi Dinkes RI, 2001, 1997; Srikandi Fardiaz, 1992; Juli Soemirat, 2000; Depkes RI,2001; Kertasapoetra, Marsetyo, Med, 2001; Mukono, 2000; Dinkes Prov. Jateng, 2005; Markum, 2002; I Dewa Nyoman Supariasa, Bachsyar Bakri dan Ibnu Fajar, 2002). 
7. Sari, N. L. E., Marlinae, L., \& Noor, F. A. (2016). Hubungan kesehatan rumah tinggal terhadap kejadian pneumonia balita di Desa Sambangan Kecamatan Bati-Bati Kabupaten Tanah Laut. Jurnal
Publikasi Kesehatan Masyarakat, 1(1), 34-43.

8. Saryono, 2008.Prosedur Penelitian Suatu Pendekatan Praktek. Edisi Revisi V, Rineka Cipta, Jakarta. 